\title{
Urinary coenzyme Q10 as a diagnostic biomarker and predictor of remission in a patient with ADCK4-associated Glomerulopathy: a case report
}

\author{
Yan Zhang, Xiaohua Liao, Yupeng Jiang, Xin Lv, Yue Yu, Qin Dai, Liyun Ao, Lijian Tao and Zhangzhe Peng*
}

\begin{abstract}
Background: AarF domain-containing kinase 4 (ADCK4)-associated glomerulopathy is a mitochondrial nephropathy caused by mutations in the ADCK4 gene, which disrupt coenzyme Q10 biosynthesis.

Case presentation: We report the case of a 25-year-old female patient with ADCK4-associated glomerulopathy presenting with proteinuria (and with no additional systemic symptoms). A known missense substitution c.737G > A (p.S246N) and a novel frameshift c.577-600del (p.193-200del) mutation were found. We followed the patient for 24 months during supplementation with coenzyme Q10 $(20 \mathrm{mg} / \mathrm{kg} / \mathrm{d}-30 \mathrm{mg} / \mathrm{kg} / \mathrm{d})$ and describe the clinical course. In addition, we measured serum and urine coenzyme Q10 levels before and after coenzyme Q10 supplementation and compared them with those of healthy control subjects. The patient's urinary coenzyme Q10 to creatinine ratio was higher than that of healthy controls before coenzyme Q10 supplementation, but decreased consistently with proteinuria after coenzyme Q10 supplementation.

Conclusions: Although the use of urinary coenzyme Q10 as a diagnostic biomarker and predictor of clinical remission in patients with ADCK4-associated glomerulopathy should be confirmed by larger studies, we recommend measuring urinary coenzyme Q10 in patients with isolated proteinuria of unknown cause, since it may provide a diagnostic clue to mitochondrial nephropathy.
\end{abstract}

Keywords: ADCK4 mutation, Coenzyme Q10, Proteinuria, Biomarker, Case report

\section{Background}

Persistent proteinuria is a warning sign of a variety of kidney diseases, often requiring more intensive tests, such as a renal biopsy. Mitochondrial dysfunction due to mutations in genes encoding proteins involved in energy production can lead to kidney diseases $[1,2]$. These disorders present clinically as nephrotic syndrome, renal tubular dysfunction and renal dysfunction with proteinuria [3]. As an essential molecule involved in electron

\footnotetext{
* Correspondence: pengzhangzhe@csu.edu.cn Department of Nephrology, Xiangya Hospital, Central South University, Changsha 410008, Hunan, China
}

transport in the respiratory chain, coenzyme Q10 (CoQ10) plays a crucial role in maintaining normal mitochondrial function. The AarF domain containing kinase 4 (ADCK4) gene is located on human chromosome $19 \mathrm{q} 13.2$ and encodes a protein that is involved in the synthesis of CoQ10 [4]. The kidney biopsy often suggests focal segmental glomerulosclerosis (FSGS) in ADCK4-associated glomerulopathy. CoQ10 supplementation could be an effective treatment, and indeed, there are reports of successful treatment of patients with ADCK4 mutations using CoQ10 (Table 1) [4-7].

(C) The Author(s). 2020 Open Access This article is licensed under a Creative Commons Attribution 4.0 International License, which permits use, sharing, adaptation, distribution and reproduction in any medium or format, as long as you give appropriate credit to the original author(s) and the source, provide a link to the Creative Commons licence, and indicate if changes were made. The images or other third party material in this article are included in the article's Creative Commons licence, unless indicated otherwise in a credit line to the material. If material is not included in the article's Creative Commons licence and your intended use is not permitted by statutory regulation or exceeds the permitted use, you will need to obtain permission directly from the copyright holder. To view a copy of this licence, visit http://creativecommons.org/licenses/by/4.0/ The Creative Commons Public Domain Dedication waiver (http://creativecommons.org/publicdomain/zero/1.0/) applies to the data made available in this article, unless otherwise stated in a credit line to the data. 


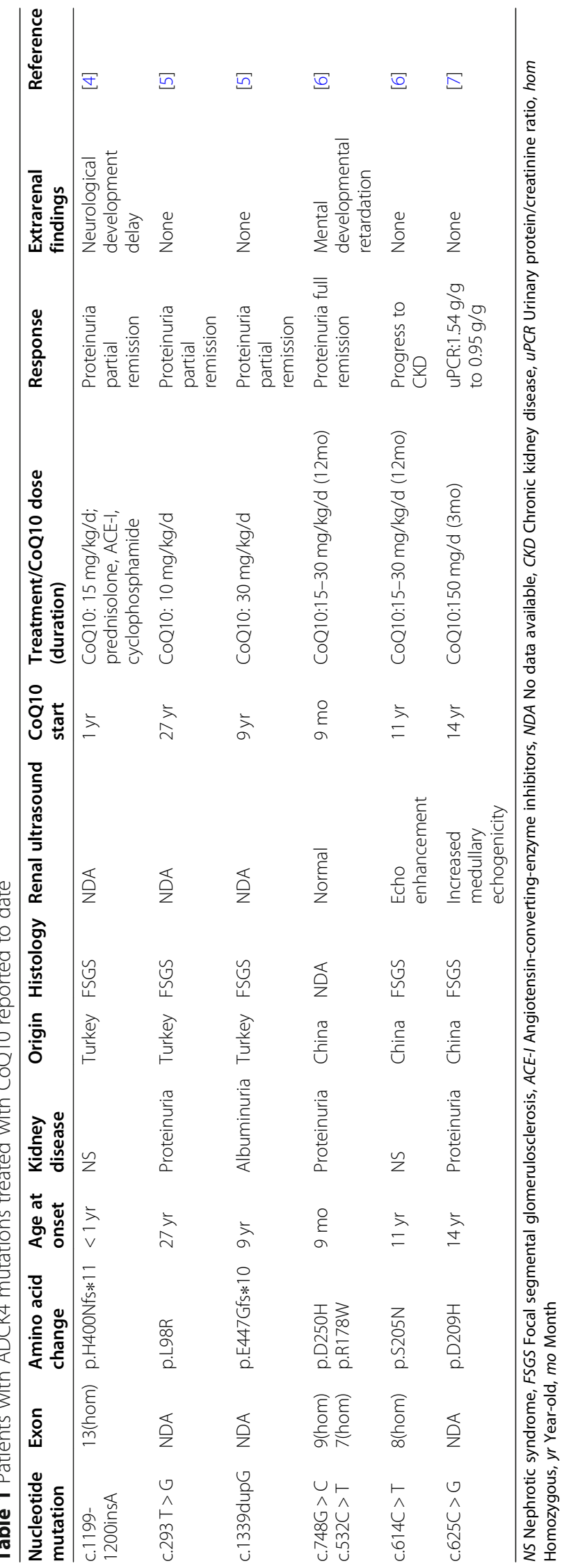


Here, we report the case of a 25-year-old female patient with ADCK4-associated glomerulopathy, with heavy proteinuria, but no systemic symptoms. During a 24-month follow-up, she showed a significant reduction in urinary protein after CoQ10 supplementation.

\section{Case presentation}

A 25-year-old woman was examined at nephrology outpatient clinic due to $3+$ proteinuria discovered during a physical examination. She had no history of hematuria, edema, arthralgia, rash or other manifestations. Laboratory tests revealed hypoalbuminemia $(35.0 \mathrm{~g} / \mathrm{L})$ and elevated blood lipid (high density lipoprotein, $1.88 \mathrm{mmol} / \mathrm{L}$ ) and creatinine $(1.19 \mathrm{mg} / \mathrm{dL})$. Her urinary protein excretion was $2.62 \mathrm{~g} / 24 \mathrm{~h}$. Anti-neutrophil cytoplasmic antibodies, complement $\mathrm{C} 3$ and $\mathrm{C} 4$, anti-nuclear antibodies and other systemic lupus erythematosus-related tests were negative. Treatment with an angiotensin receptor blocker (ARB) (candesartan, 4-8 mg, orally once daily) was recommended. Three months later, her proteinuria was $4+$. At that point, she was admitted to the nephrology department for a kidney biopsy.

The patient denied any history of hypertension, diabetes or viral hepatitis, but had a history of allergic purpura after eating seafood. There were no manifestations of heart or neuromuscular diseases. She was a student who consumed a regular diet and followed a routine in her daily life. Her parents were both healthy, without a history of consanguineous marriages or similar diseases in their families. On physical examination, no positive signs were found.

After admission, the urinalysis showed proteinuria (protein excretion, $5.39 \mathrm{~g} / 24 \mathrm{~h}$ ). Urine specific gravity, osmotic pressure, and blood/urine light chain ratio were within the normal range. Evaluation revealed impaired renal function with elevated serum creatinine $(1.38 \mathrm{mg} /$ $\mathrm{dL})$ and hypoalbuminemia (32.6 g/l), but without hypercholesterolemia or peripheral edema. The Doppler ultrasound showed a thin renal cortex with bilateral renal vertebral echo enhancement, suggestive of a medullary sponge kidney (Fig. $1 \mathrm{~A}, \mathrm{~B}$ ). The left kidney measured $97 \times 43 \mathrm{~mm}$, and the right kidney $89 \times 35 \mathrm{~mm}$. The patient was not subjected to a renal biopsy due to her small kidneys and thin renal cortices.

The patient underwent genetic analysis and continued taking an ARB (valsartan, $80 \mathrm{mg}$, orally once daily). Whole exome sequencing demonstrated compound heterozygote mutations in the ADCK4 (CQ8B) gene involving two pathogenic variants: a known missense substitution c.737G > A (p.S246N) and a novel frameshift c.577-600del (p.193-200del) mutation. In addition to ADCK4, we also identified another mutation: a c.2173A > G (p.K725E) mutation in chr2-228,144,556 affecting the COL4A3 gene (Table 2).
After genetic diagnosis, the patient began treatment with CoQ10 supplement at a dose of $20 \mathrm{mg} / \mathrm{kg}$ per day. After 6 months, her urinary protein decreased significantly from $5.39 \mathrm{~g} / 24 \mathrm{~h}$ to $0.70 \mathrm{~g} / 24 \mathrm{~h}$, and her serum creatinine levels remained stable $(1.47 \mathrm{mg} / \mathrm{dL})$. The patient did not experience any side effects during the treatment, so we recommended that she continue taking the supplement CoQ10 at a dose of $30 \mathrm{mg} / \mathrm{kg}$ per day [5]. After 10 months of treatment with CoQ10 and ARB, her urinary protein remained stable at $1.00 \mathrm{~g} / 24 \mathrm{~h}$. Renal ultrasonography showed normal echogenicity of the kidneys after treatment with CoQ10 (Fig. 1 C, D). However, from then on, the patient only complied with the ARB treatment but did not follow our advice to continue taking CoQ10. Seven months later, her urinary protein rose to $4.22 \mathrm{~g} / 24 \mathrm{~h}$. Based on this result, we recommended her to continue taking the CoQ10 supplement regularly. After another 2 months, her urinary protein decreased from $4.22 \mathrm{~g} / 24 \mathrm{~h}$ to $2.38 \mathrm{~g} / 24 \mathrm{~h}$. Glomerular filtration rate remained stable throughout the clinical course. Changes in proteinuria and glomerular filtration rate (eGFR) in the course of treatment are summarized in Fig. 2 and Fig. S1.

We measured the concentration of CoQ10 in the urine of the patient before and after treatment, and corrected it with urinary creatinine. The results showed that the ratio of urinary CoQ10 to creatinine in the patient before treatment $(0.739 \mathrm{ng} / \mathrm{mg})$ was nearly 5 times higher than in healthy controls (average value: $0.157 \mathrm{ng} / \mathrm{mg}$, $95 \%$ confidence interval: 0.036-0.205) whose eGFR were in normal range and proteinuria were negative. However, after CoQ10 supplementation the ratio decreased (after 6-months: $0.454 \mathrm{ng} / \mathrm{mg}$; after 10 -months: $0.470 \mathrm{ng} / \mathrm{mg}$ ) but was still nearly 3 times higher than in healthy controls (Fig. 2). On the other hand, the serum levels of CoQ10 in the patient before and after treatment were comparable to those of healthy controls.

\section{Discussion and conclusions}

Coenzyme Q10 is a lipid-soluble quinone present in the mitochondrial inner membrane of eukaryotic cells that participates in many important biochemical reactions during electron transport. It modulates metabolism and cell differentiation [8]. To date, 15 genes involved in CoQ10 biosynthesis have been identified in humans. Mutations in eight of them (PDSS1, PDSS2, COQ2, COQ4, COQ6, ADCK3, ADCK4 and COQ9) cause primary CoQ10 deficiency, which result in several disorders [9]. In the first and largest to date multicenter cohort study of Chinese pediatric patients with steroid-resistant nephrotic syndrome (SRNS), ADCK4 was identified as the most common pathogenic gene [10]. So far, only a few studies have described the response of patients with 


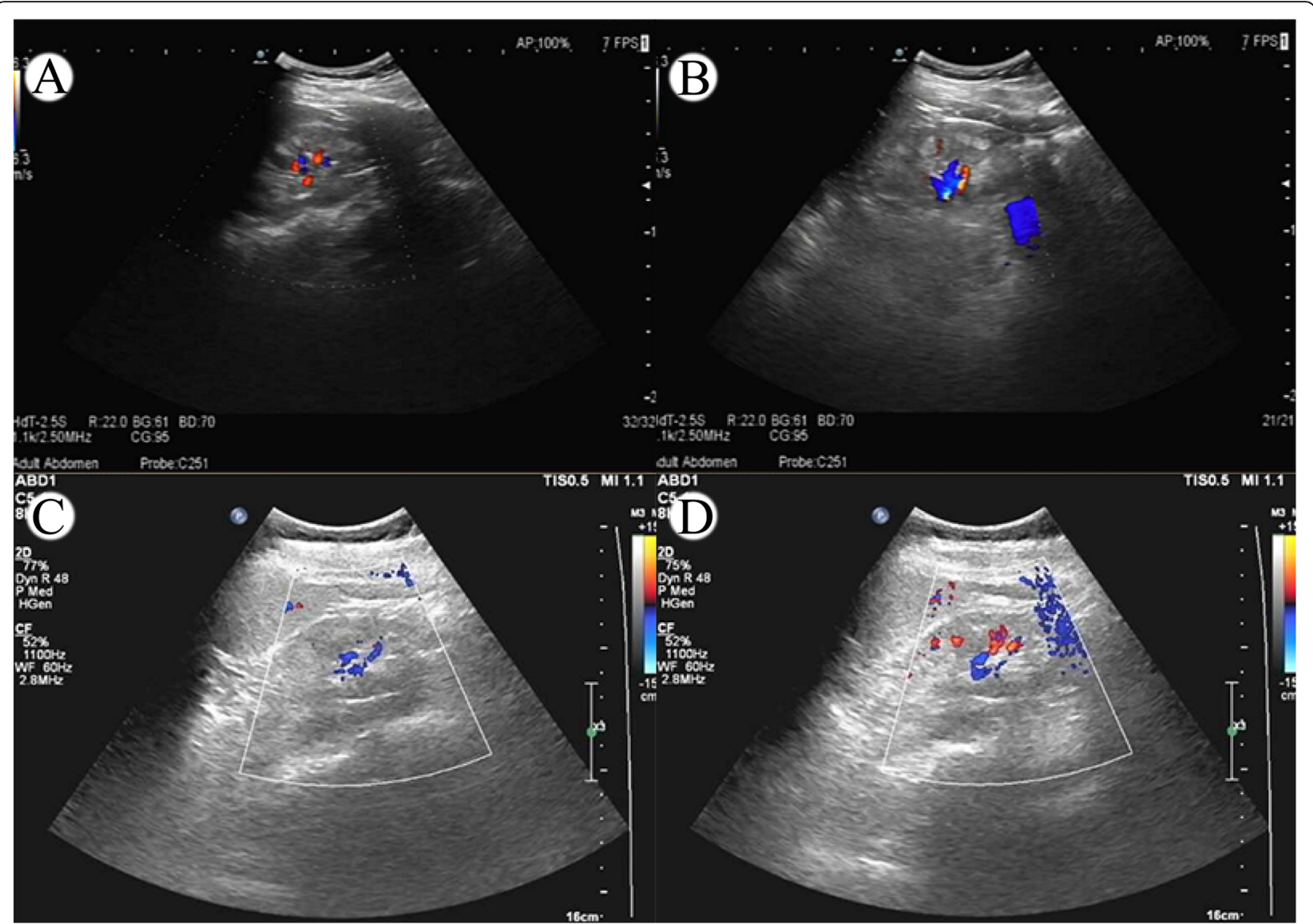

Fig. 1 Renal ultrasonography findings in the patient before and after CoQ10 treatment. $\mathbf{a}$, $\mathbf{b}$ Increased echogenicity of renal medullae before treatment with CoQ10. c, d Normal kidney echogenicity after treatment with CoQ10

kidney disease due to ADCK4 mutations in an early stage to treatment with CoQ10. All the cases described presented with proteinuria, and the kidney biopsies of most individuals showed FSGS. Other concomitant symptoms which have been described include neurologic developmental delay, mental retardation, occasional seizures and retinitis pigmentosa [4-7].

In this patient the sole clinical manifestation was persistent proteinuria, and genetic testing revealed complex heterozygous ADCK4 (COQ8B) mutations.
During the 24-month follow-up, we observed that her proteinuria decreased significantly after taking CoQ10, but worsened after interruption of treatment with CoQ10. Serum creatinine levels in the patient remained stable and no side effects were observed during the follow-up. Based on the response of our patient to CoQ10, we believe that supplementation with oral CoQ10 may reverse proteinuria in adultonset ADCK4-associated glomerulopathy, not only in early or adolescent-onset patients.

Table 2 The results of the next-generation sequencing of the patient

\begin{tabular}{|c|c|c|c|c|c|c|c|c|}
\hline $\begin{array}{l}\text { Variant } \\
\text { gene }\end{array}$ & Location & $\begin{array}{l}\text { Transcriptional } \\
\text { exons }\end{array}$ & $\begin{array}{l}\text { Nucleotide } \\
\text { amino acids }\end{array}$ & $\begin{array}{l}\text { Homozygous } \\
\text { /heterozygous }\end{array}$ & $\begin{array}{l}\text { Prevalence in } \\
\text { Control } \\
\text { population }\end{array}$ & $\begin{array}{l}\text { Analysis of } \\
\text { pathogenicity }\end{array}$ & $\begin{array}{l}\text { Phenotype of } \\
\text { mutation }\end{array}$ & Source \\
\hline COL43A & $\begin{array}{l}\text { chr2-228,144, } \\
556\end{array}$ & $\begin{array}{l}\text { NM-000091; } \\
\text { exon29 }\end{array}$ & $\begin{array}{l}c .2173 \mathrm{~A}>\mathrm{G} \\
(\mathrm{p} . \mathrm{K} 725 \mathrm{E})\end{array}$ & Het & Not reported & Uncertain & $\begin{array}{l}\text { Alport syndrome; } \\
\text { familial hematuria }\end{array}$ & Father \\
\hline COQ8B & $\begin{array}{l}\text { chr19-41,209, } \\
508\end{array}$ & $\begin{array}{l}\text { NM-024876; } \\
\text { exon9 }\end{array}$ & $\begin{array}{l}\text { c. } 737 \mathrm{G}>\mathrm{A} \\
(\mathrm{p} . \mathrm{S} 246 \mathrm{~N})\end{array}$ & Het & 0.00435 & Uncertain & $\begin{array}{l}\text { Type } 9 \text { nephrotic } \\
\text { syndrome }\end{array}$ & Father \\
\hline COQ8B & $\begin{array}{l}\text { chr19-41,209, } \\
\text { 736-41,209,778 }\end{array}$ & $\begin{array}{l}\text { NM-024876; } \\
\text { exon8 }\end{array}$ & $\begin{array}{l}\text { c.577-600del } \\
\text { (p.193-200del) }\end{array}$ & Het & Not reported & Uncertain & $\begin{array}{l}\text { Type } 9 \text { nephrotic } \\
\text { syndrome }\end{array}$ & Mother \\
\hline
\end{tabular}

Sequencing analysis of the patient demonstrating the detection of c.737G > A (p.S246N) mutation in exon 9 and c.577-600del AGAGTTCTTGAAGGGAGCTCGGC (p.193-200del) in exon 8 of the COQ8B gene 


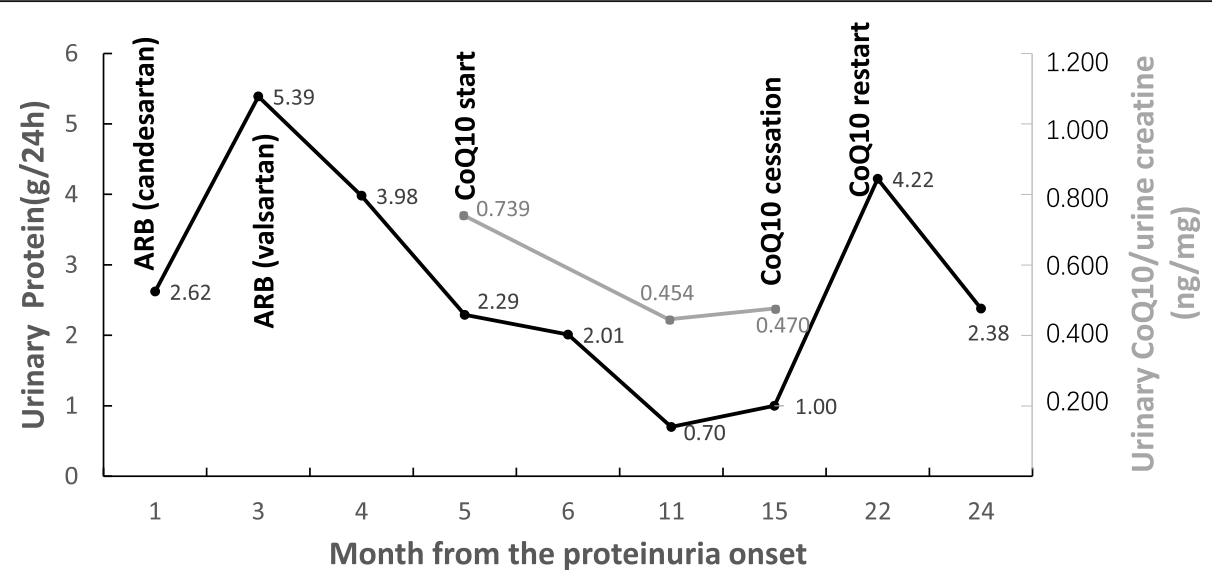

Fig. 2 Changes of 24-h urinary protein excretion $(g / 24 h)$ and urinary coenzyme Q10 to creatinine ratio in the course of treatment

The only available method to confirm the diagnosis of ADCK4-associated glomerulopathy is genetic testing, but this cannot be carried out routinely because of its high cost and the length of time needed for completion. This often leads to missed diagnosis and misdiagnosis. CoQ10 levels can be measured in different specimens, such as plasma, serum, blood mononuclear cells, platelets, urine, muscle and cultured skin fibroblasts [11]. We found that the ratio of urinary $\mathrm{CoQ} 10$ to creatinine in our patient before treatment was nearly 5 times higher than in healthy controls. Following the treatment with CoQ10, there was a marked decrease in urinary CoQ10, which was consistent with proteinuria remission. Interestingly, this phenomenon is consistent with the change of plasma CoQ10 in a patient with proteinuria caused by a COQ6 gene defect [12]. The decrease of urinary CoQ10 concentration in our patient during therapy is unclear. In general the urinary CoQ10 concentration is mainly affected by de novo synthesis [13]. Perhaps other tissues may have some compensatory effect for the de novo synthesis of CoQ10, which makes urinary CoQ10 in patient with ADCK4-associated glomerulopathy higher than that of healthy controls. This compensatory effect was weakened after exogenous supplementation with $\mathrm{CoQ} 10$, resulting in a decrease in urinary coenzyme q10. Hence, noninvasive evaluation of urinary CoQ10 may be useful and convenient for the diagnosis of ADCK4-associated glomerulopathy and for monitoring the effects of treatment.

It is also worth noting that the patient's renal color Doppler ultrasound suggested a "medullary sponge kidney" (Fig. 1 A, B) and that her renal medullae returned to normal after treatment with CoQ10 (Fig. 1 C, D). In 2017, it was reported that renal ultrasound examination of 7 patients with ADCK4 mutations showed "enhanced echogenicity of the renal medulla", which is considered as medullary nephrocalcinosis, but that no related manifestations of medullary sponge kidney were found [14]. In addition, a few studies also reported increased medullary echogenicity in ADCK4-associated glomerulopathy $[6,7,15]$. Whether there is a correlation between renal medullary lesions detected by ultrasound and ADCK4-associated kidney disease remains to be explored. This could be another useful clinical diagnostic sign of mitochondrial nephropathy.

In conclusion, ADCK4-associated glomerulopathy should be considered not only in children but also in young adults with isolated proteinuria of unknown cause. Considering that genetic testing is expensive and time-consuming, the ratio of urinary CoQ10 to creatinine may be a suitable diagnostic biomarker and a predictor of remission in patients with primary coenzyme Q10 deficiency of the kidney. Patients with an elevated ratio of urinary CoQ10 to creatinine and increased medullary echogenicity can be treated empirically with a CoQ10 supplement. Although the clinical response to CoQ10 was evident in our patient, more information is needed about its effectiveness in order to determine when to suspect ADCK4-associated glomerulopathy and which patients with proteinuria should be treated with CoQ10.

\section{Supplementary Information}

The online version contains supplementary material available at https://doi. org/10.1186/s12882-020-02208-7.

Additional file 1: Fig. S1 Patient's glomerular filtration rate (eGFR) (mL/ min) during a 22 months follow-up.

\section{Abbreviations}

ADCK4: AarF domain-containing kinase 4; ARB: Angiotensin receptor blocker; CoQ10: Coenzyme Q10; FSGS: Focal segmental glomerulosclerosis;

SRNS: Steroid-resistant nephrotic syndrome

Acknowledgements

Not applicable. 


\section{Authors' contributions}

The authors contributed as following: YZ, ZZP and LT: study design; YZ, XHL and YPJ: data collection and experiment; $Y Z, Z Z P, X L, Y Y, Q D$ and LYA: literature search; YZ, ZZP and LJT: data analysis; YZ and ZZP: writing of the manuscript. The authors have read and approved the manuscript.

\section{Funding}

This project was supported by the National Natural Science Foundation of China (grant no. 81673499) and Natural Science Foundation of Hunan Province (grant no. 2018JJ3835). The funding bodies had no role in the design of the study and collection, analysis, or interpretation of data, in the writing of the manuscript or the decision to submit the manuscript for publication.

\section{Availability of data and materials}

Additional data used/generated that is not present in the manuscript is available from the corresponding author upon reasonable request.

\section{Ethics approval and consent to participate}

Written informed consent was obtained from all participants involved in the study and the study was approved by the Institute's Committee of Xiangya hospital, Central South University.

\section{Consent for publication}

Written informed consent for publication of their clinical details and clinical images was obtained from the patient of the patient. A copy of the consent form is available for review by the Editor of this journal.

\section{Competing interests}

The authors declare that they have no competing interests.

Received: 5 May 2020 Accepted: 13 December 2020

Published online: 07 January 2021

\section{References}

1. Lightowlers RN, Taylor RW, Turnbull DM. Mutations causing mitochondrial disease: what is new and what challenges remain? Science. 2015;349(6255): 1494-9.

2. Tranchant C, Anheim M. Movement disorders in mitochondrial diseases. Rev Neurol (Paris). 2016;172:524-9.

3. Kurogouchi F, Oguchi T, Mawatari E, Yamaura S, Hora K, Takei M, et al. A case of mitochondrial cytopathy with a typical point mutation for MELAS, presenting with severe focal-segmental glomerulosclerosis as main clinical manifestation. Am J Nephrol. 1998;18(6):551-6

4. Ashraf S, Gee HY, Woerner S, Xie LX, Vega-Warner V, Lovric S, et al. ADCK4 mutations promote steroid-resistant nephrotic syndrome through CoQ10 biosynthesis disruption. J Clin Invest. 2013:123(12):5179-89.

5. Korkmaz E, Lipska-Zietkiewicz BS, Boyer O, Gribouval O, Fourrage C, Tabatabaei M, et al. ADCK4-associated Glomerulopathy causes adolescenceonset FSGS. J Am Soc Nephrol. 2016;27(1):63-8.

6. Feng C, Wang Q, Wang J, Liu F, Shen H, Fu H, et al. Coenzyme Q10 supplementation therapy for 2 children with proteinuria renal disease and ADCK4 mutation: case reports and literature review. Medicine (Baltimore). 2017:96(47):e8880.

7. Yang J, Yang Y, Hu Z. A novel ADCK4 mutation in a Chinese family with ADCK4-associated glomerulopathy. Biochem Biophys Res Commun. 2018; 506(3):444-9.

8. Quinzii CM, Hirano M. Primary and secondary CoQ (10) deficiencies in humans. Biofactors. 2011;37(5):361-5.

9. Desbats MA, Lunardi G, Doimo M, Trevisson E, Salviati L. Genetic bases and clinical manifestations of coenzyme Q10 (CoQ 10) deficiency. J Inherit Metab Dis. 2015;38(1):145-56.

10. Wang F, Zhang Y, Mao J, Yu Z, Yi Z, Yu L, et al. Spectrum of mutations in Chinese children with steroid-resistant nephrotic syndrome. Pediatr Nephrol. 2017;32(7):1181-92.

11. Yubero D, Allen G, Artuch R, Montero R. The value of coenzyme Q10 determination in mitochondrial patients. J Clin Med. 2017:6(4):37.

12. Stańczyk M, Bałasz-Chmielewska I, Lipska-Ziętkiewicz B, Tkaczyk MJP. CoQ10related sustained remission of proteinuria in a child with $\mathrm{COO} 6$ glomerulopathy-a case report. Pediatr Nephrol. 2018;33(12):2383-7.
13. Nakamura T, Ohno T, Hamamura K, Sato TJB. Metabolism of coenzyme Q10: biliary and urinary excretion study in Guinea pigs. Biofactors. 1999;9:111-9.

14. Park E, Kang HG, Choi YH, Lee KB, Moon KC, Jeong HJ, et al. Focal segmental glomerulosclerosis and medullary nephrocalcinosis in children with ADCK4 mutations. Pediatr Nephrol. 2017;32(9):1547-54.

15. Lolin K, Chiodini BD, Hennaut E, Adams B, Dahan K, Ismaili K. Early-onset of ADCK4 glomerulopathy with renal failure: a case report. BMC Med Genet. 2017;18(1):28.

\section{Publisher's Note}

Springer Nature remains neutral with regard to jurisdictional claims in published maps and institutional affiliations.
Ready to submit your research? Choose BMC and benefit from:

- fast, convenient online submission

- thorough peer review by experienced researchers in your field

- rapid publication on acceptance

- support for research data, including large and complex data types

- gold Open Access which fosters wider collaboration and increased citations

- maximum visibility for your research: over $100 \mathrm{M}$ website views per year

At BMC, research is always in progress.

Learn more biomedcentral.com/submission 